Cadernos de Literatura em Tradução, n. 5, p. 149-155

\title{
The new voice of Goiás
}

Alison Entrekin

This short story was taken from Goianian writer Augusta Faro's first book of short stories, entitled A Friagem (Editora Global). Originally a poet and writer of children's literature, Faro's complex prose is finely crafted and employs stunning imagery with poetic precision. Her work is largely concerned with solitude and the human condition, and the collection of stories in A Friagem form an intricate tapestry of literary genres, with elements of the fantastic and the absurd, at times distinctly post modern. One enters a world in which a doll narrates her own destruction and a Chinese dragon etched into the side of a vase, climbs down from its etching at night and roams the house, terrorising the protagonist and pushing her and the reader - toward the limits of reason, where sanity becomes subjective. Faro's protagonists are women and the narrative voice of her stories is distinctly female, rich with nuances at once regional and universal.

The following story, "The Cage", appeared in the original as "A Gaiola".

\section{The Cage by Augusta Faro}

Because my plaits were soft and lustrous, and the skin of my face tasted of velvety fruit, fresh and shot with colour, I lay back that day beneath the glass tile in the roof of the cage, in the long 
hammock laced with the perfume of black home-made soap. This was the beginning of a crooked fate, which branded my forehead and made me drag a part of my heart through life like a lump of hardened meat. Not long after that my hair began to turn grey at the temples and my eyes decided to burrow in, becoming two bluishgreen ponds clouded over by the haze from the chimney of the house where I leant my belly against the edge of the stove while seasoning the children's soup and boiling the milk, because my own milk had dried up early on and I had to use milk from the goats in the large gravely yard, and also because my great grandmother, who still spoke and prayed in a shred of a voice and covered herself in a corner of the dark room like a stain in the void, insisted that bright-eyed children with strong teeth should drink goats' milk as their mothers dried up so early, inside and out, because they tore so much marrow and sustenance from the gravy of blood and bones to knead the day of the husband who would come along with his voice raised as if he had been born a king and the flock of children, his first subjects.

And he would run his hand over his moustache and the backsides of the helpers of the sunken-eyed mother who was always pregnant and wilting in silence, and the ticking of the clock changed very little.

In all that confusion, I was no longer sure if I was the one with the soft plaits with large golden streaks or the one hanging on the wall in the oval photograph of my aunt, already old, a black shawl about her shoulders and a very dark mesh covering her eyes, though not her lips, thin because they had stopped smiling too soon.

And the man in boots would arrive ready for lunch, expecting the polished platters to be laid out on the white tablecloth, and the wine shouldn't be long in the coming, and they had to be quiet so as not to interfere while he listened to himself chewing, nor interrupt his serious thoughts, because he was the only one in the house who thought, the others being clay puppets, though they served to tend to the bed, the table and his more urgent needs, because the 
others he could take care of elsewhere, preferably in one of those houses where the girls were neither sad nor happy, but would lie back, perfume always sweetening their fingers, heavy with rings of coloured stones, lacklustre, because when they washed their children's clothes they often forgot to remove them and leave them on the bedside table next to the cup of lemon-grass tea, calmer of daily nerves.

And time came along, weaving its lace here and there like the curtains on the drawing room windows. And my voice, already little given to speech, shrivelled into silence, and as my muteness deepened I became inflexible and forgot the art of conversation. I started napping three times a day, always on one side, because a very tender, painful rose had blossomed on my left side. I took great care to not hurt the flower, for if I did, the flesh of my own body would shudder so deeply that I could have easily slipped on the wooden floor, so heavily waxed it resembled a mirror. My worth and utility were greatly reduced now and I took to remaining in the dark, though I was not yet half the age of my great grandmother, who was still alive and prayed and cursed the things that did not please her in a shred of a voice.

My mother, dark as an Indian, never slept and continued her endless needlework with the stealth of dew, making long or colourful doilies to decorate the houses of the entire family. She even mingled with the sunlight that dawned and entered, never stopping in her toil except for a few hours when the silence and the dogs in the dark felt that the night had grown too heavy.

All the chores and labour of life made my veins wither in my arms and my wrists became so weak that things slithered from my clutch.

Once in a while someone would come into the room and I would hear, "Need something?" but what I needed, no one had ever given me, right from the very first wail of my new-born lungs. But my voice could hardly be coaxed out and those who asked never knew if an answer would come; or they were in a hurry, 
closing the door behind them, and they wouldn't have heard me even if I had shouted. But I never shouted; in fact, I had shouted very rarely even when I was stronger.

This is why I saw myself for the last time in the bedroom mirror, with the look of one who had stumbled into the world by mistake.

The mirror still hangs there, but the windows are open now and the women, daughters of the daughters I carried in my womb, look at themselves in it, but they don't lower their eyelids or close their mouths. Quite the contrary; they talk a lot with the other women and their men. I don't even worry any more, it's almost never necessary, because these women have flung open the doors and windows, aired out the house, and not all of them lie back beneath that moonlit tile of glass, nor do they swoon like china dolls when they are stroked and caressed. They have opened all of the windows and I see the sun pouring in resolutely, casting lace on the sideboards, and their chirping is so loud that no one shuts them in the cage or hangs it from the highest beam of the veranda as they did with me and many women of my generation and many other generations before I was born.

\section{A gaiola}

Porque minhas tranças estavam macias e lustrosas, a pele de meu rosto sabia a fruta veludosa, fresca e furta-cor, deitei-me naquele dia sob a telha de vidro da gaiola, na longa rede cheirosa de sabão preto feito em casa mesmo. Foi esse o início de um destino esquerdo, que me marcou a testa a fogo e me fez arrastar uma banda do coração como um toco de carne empedrado pela vida afora. Daí mais um pouco fui embranquecendo os fios do cabelo da fronte, e meus olhos acharam por bem esburacaram-se parecendo por fim a dois lagos meio verdes meio azuis, esfumaçados pela neblina que saía da chaminé daquela casa onde, à beira do fogão encostei meu umbigo temperando as sopas dos 
meninos e pondo o leite pra ferver, porque desde cedo me secaram as tetas e o jeito era recorrer ao leite das cabras do quintalão de pedras e, também porque minha bisavó, que ainda falava e orava com um fio de voz e se cobria num canto do quarto escuro, como uma mancha no ermo, dizia e repetia que crianças de dentes fortes e olhos vivos devem beber leite de cabra já que as mães se secam muito cedo, por dentro e por fora de tanto arrancarem pedacinhos de carne e sustança do suco de ossos e sangue para sovar o dia do marido que vem chegando, levantando a voz como se nascesse rei e o bando de filhos seus primeiros súditos.

E alisava o bigode e a traseira das ajudantes da mãe de olhos afundados e sempre prenhe e murchada no silêncio, e mesmo que se desse corda nos relógios, eles pouco diziam.

Naquele atropelo, nem sabia se seria eu aquela de tranças macias, com enormes riscos de fio de ouro ou se era aquela da parede suspensa na fotografia oval de minha tia, já entrada em anos, tendo um xale preto nos ombros e um véu cheio de buraquinhos e muito escuro lhe tampando o olhar e de fora os beiços que mais se afinaram, porque pararam de rir antes da hora.

E o homem de botas chegava pronto para o almoço e queria as travessas areadas na mesa de forro branco, e que não demorasse o vinho e que não fizessem barulho para não o atrapaIhar a ouvir o próprio mastigar e que não interrompessem seus pensamentos sérios, porque só ele quem pensava na casa e o resto era gente feita de barro duro e mole, mas que de alguma forma servia-lhe para ajeitar a cama, a mesa, o banho e as necessidades mais urgentes, porque as derradeiras podia arrumar nalguma esquina, de preferência naquelas casas onde as moças nem eram tristes nem eram alegres, mas deitavam tendo sempre um perfume adocicado nos dedos cheios de anéis de pedras de cores meio foscas, pois muitas vezes quando lavavam roupa dos filhos se esqueciam de tirá-los e deixá-los sobre a mesinha da cabeceira junto ao chá de erva cidreira, que é minguador do nervoso de cada dia. 
ENTREKIN, Alison. The new voice of Goiás.

E foi entrando o tempo de lá para cá, tecendo um rendado feito as cortinas costuradas na janela da sala de visitas. E minha voz, que já pouco falava, foi emudecendo de fora para dentro e no que mais emudeci, perdi o jogo de cintura e o gosto da língua. Comecei a repousar três vezes ao dia, sempre de lado, porque abriu uma rosa muito macia e dolorida do lado esquerdo; todo cuidado é pouco, porque, se ferisse a flor, a carne de meu próprio corpo tremia tanto, que poderia cair no assoalho mais parecido a um espelho de tanta cera. Pouco é a minha valia e serventia agora e, por isto, passei a ficar no escuro, embora não chegasse nem à metade da idade de minha bisavó, que ainda vivia e num fio de voz orava e danava com as coisas das quais não apetecia.

Minha mãe, por ser morena como uma índia, nunca dormia e feita de sereno não cansava de trabalhar nas tarefas de aguIhas, fazendo uns panos compridos, outros coloridos e enfeitando a casa da família inteira. Ela até se misturava com o sol, que nascia e que entrava, não parando a sua labuta, a não ser por poucas horas, quando o silêncio e os cachorros no escuro sentiam que a noite era pesada demais.

Por causa dos quefazeres todos e do aloite com a vida, minhas veias murcharam nos braços e as coisas me caíam das mãos dado à fraqueza que rodeava meus pulsos.

De vez em quando, alguém entrava no quarto e bem eu ouvia "precisa de alguma coisa?", mas o que eu precisava ninguém me dera nunca, desde que vagi primeiro. Também a minha voz pouco queria sair e quem perguntava nem sabia se haveria resposta ou estava com pressa, iá fechava a porta atrás de si, e nem que eu gritasse não ouviria mesmo. Mas eu não gritava nun$\mathrm{ca}$, aliás, pouco gritei enquanto mais forte.

Foi por isso que no espelho do quarto me vi pela última vez, com jeito de quem veio errado viajar no mundo.

O espelho ainda está lá pendurado, mas as janelas abriram e as moças, filhas das filhas que carreguei no ventre, se olham nele mas não abaixam as pestanas, nem calam a boca. Pelo con- 
trário, falam muito umas com as outras e com os homens lá delas. Até que não me preocupo mais, quase nem é preciso, porque essas moças abriram as portas e janelas, arejaram a casa e nem todas vão se deitando sob a telha de vidro enluarado nem ficam encantadas feito bonecas de louça quando thes alisam os cabelos e os pêlos. Elas abriram todas as janelas e vejo que o sol entra com vontade, deixando um tendado nas tábuas, de modo que os piados delas são fortes o bastante para que não as fechem na gaiola nem a dependurem no caibro mais alto da varanda, igual foi acontecido comigo e muitas mulheres da minha geração e de muitas outras gerações antes de eu nascer.

A publicação do conto "A Gaiola" de Augusta Faro foi gentilmente autorizada pela Global Editora. 